\title{
National Security and Wealth Creation: The Nigerian Sustainable Growth Nightmare
}

\author{
Benedict Azu, Dominic Mario Uduh \& Andrew I. Mobosi \\ http://dx.doi./org/10.4314/ujah.v21i4.14
}

\begin{abstract}
Insecurity has been one of the many challenges implicated as the biggest developmental and growth obstacle facing Nigeria as a nation. Since the independent in 1960, the country developmental strides have been hampered by one form of insecurity or the other. The country over the decades has experienced high rate of poverty, youth unemployment, widening income disparity, clashes and conflict, and violence among others with over $70 \%$ of her population living below poverty line. Security is undoubtedly the pillar upon which every meaningful development could be achieved and sustained. Lend credence to this assertion, most advanced nations of the world place high premium on security. Whilst Nigeria is richly blessed with abundant natural resources and human capital, negligence to numerous challenges of insecurity of the environment appears to have created porous security condition that engendered violence and retards growth and development. This paper is designed to empirically establish the nexus between national security and wealth creation in Nigeria. It also estimates the effect of national security on sustainable growth in Nigeria. Noting that insecurity affect growth with time lag, an Autoregressive Distributed Lag (ARDL) Model is built for the analysis. It is expected that security exacts positive time lag effects on growth, whilst insecurity negates sustainable growth.
\end{abstract}

\section{Introduction}

The symbiotic bond linking national security, wealth creation and sustainable economic growth cannot be diluted. The interplay 
between the environment and the economy remains at the heart of sustainable development (Pearce \& Barbier, 2000). In Africa, Nigeria is a country blessed by vast human and natural resources. It is expected that the exploitation and utilization of these resources will no hesitation enhance the growth of the nation, but in spite of the exploitation and utilization of these resources, the nation is bedevilled by serious crises of national security and economic growth.

The national security of any nation encompasses other vital areas such as environmental protection, social and food security and more especially the prevalence of internal peace. Without adequate security of lives and property, the system will be rife with lawlessness, chaos and eventual disintegration. It might be military, economic, ideological or cultural (Omede, 2011). The people must not only be secured from external attacks but also from devastating consequences of internal upheavals, unemployment, hunger, starvation, diseases, ignorance, homelessness, environmental degradation and pollution cum socio-economic injustices. Security is vital for national cohesion, peace and sustainable development. It is therefore apparent that national security is a desideratum, sine qua non for economic growth and development of any country (Oladeji \& Folorunso, 2007, Ewetan \& Urhie, 2014).

National security is a veritable tool for the achievement of inclusive wealth creation, growth and consequently sustainable development. There are many opens security can guarantee in Nigeria given the demographic dividends. The youths that constitute about 60 percent of the Nigeria population which suppose to be at the centre of industrial impacts, agriculture, trade and commerce policy formulation and implementation, however because of the deplorable state of wellbeing in the country, a sizeable number of youths are now employed as touts and thugs by politicians to chaos at rallies. 
Economic growth as a measurement of wealth creation for the nation that comes from the economic activities which are supported by the government's contribution to the business conduct and facilitation in terms of public goods creation. Lymer (2010) and Chigbu and Njoku (2015) are of the opinion that government should have a sound and fair fiscal policy which allows for economic stability, employment provision, externalities balance and sustained economy so that its nation should continually develop and secure its future for the citizenry.

The state of national insecurity in Nigeria has fuelled the crime rate and terrorist attacks indifferent parts of the country, leaving unpalatable consequences for the nation's economic growth. To address the threat to national security and combat the increasing waves of crème the federal government in 2013,2014 and 2015 budget made huge allocation to security and the national assembly passed the Anti- terrorism act in 2011 (Ewetan, 2014). Regardless of these efforts, the level of insecurity in the country is still high, and a confirmation of this is the low ranking of Nigeria in the Global peace index (GPI, 2012,2014 \&2016). Despite the plethora of security measures taken to address the daunting challenges of insecurity in Nigeria, government efforts have not produced the desired result. This has compelled the Nigerian government in the recent time to request for foreign aids from developed nations such as USA, Israel and EU countries to combat the rising waves of terrorism and insecurity.

The rising wave of crimes in the form of electoral malpractices, commercial violence or economic terrorism and motor par rent seeing among bothers are common cases to ponder. The huge infrastructure deficits - road, power, water etc., inadequate access to credit and disastrous policy regime constrain wealth creation towards achieving enhanced and sustainable economic wellbeing. The national security harms of Nigeria pivot on the factors of the country's 
economic underdevelopment, which has led to severe food shortage, persistent problem of unemployment, low level of productivity, large domestic debt, rising stock of external debt, low industrial output, high inflation rate, unstable and deteriorating exchange rate weak infrastructure base for technological growth, and explosive population growth, inadequate and inefficient public utilities (Ewetan, 2013).

Any country that seeks to achieve national security, wealth creations and economic growth with the above mentioned features has a bogus sense of security and development. Against this background, the paper therefore seeks to examine the pertinent issue of national security, wealth creation and economic growth in Nigeria. The specific objectives include

i. To establish the nexus between national security and wealth creation in Nigeria.

ii. To investigate the effect of national security on economic growth in Nigeria.

\section{Brief Literature Review \\ 2.1 National security}

Issues relating to security were on the front burner in the development discourse. Several attempts have been made since the cold war ended to redefine the concept of security. At the heart of this debate there have been attempts to deepen and widen the concept of security from the level of the states to societies and individuals, and from military to non-military issues (Nwanegbo \& Odigbo, 2013, Ewetan \& Urhie, 2014).

According to Williams, (2008), security as an essential concept is commonly associated with the alleviation of threats to cherished values, especially the survival of individuals, groups or objects in the near future. Adebakin, (2012) however defines security as activities that ensure protection of a country, persons, properties of the community against future threats, danger, mishaps and all other 
forms of perils. Babangida (2011) on the other hand views national security "as the physical protection and defence of our citizens and our territorial integrity and also the promotion of the economic wellbeing and prosperity of Nigerians in a safe and secure environment that promotes the attainment of our national interests and those of our foreign partners."

Furthermore, Otto and Ukpere (2012) and Adebakin, (2012) asserts that "security means protection from hidden and hurtful disruptions in the patterns of daily life in homes, offices or communities. Security must be related to the presence of peace, safety, happiness and the protection of human and physical resources or the absence of crisis, threats to human injury among others". Security is considered as any mechanism deliberately fashioned to alleviate the most serious and immediate threats that prevent people from pursuing their cherished values (Chris, 2012). Orji, (2012) posits that pivotal to the survival of any society is its law and order which are predicated on national security.

National security must be broadened to accommodate economic, environmental and demographic issues as they are important in understanding the new causes of intra-state conflicts. Other dangers that serve as threat to national security include pollution, poverty, crime, and underdevelopment all of which fuel conflicts (Onigbinde, 2008). The United Nations Development Programme (1994 \& 1996) posits that human security (an aspect of national security) refers to "freedom from fear and freedom from want" and "safety from chronic threats such as hunger, disease, and repression as well as protection from sudden and harmful disruptions in the patterns of daily life - whether in homes, in jobs or in communities." National security can summarily be describes as "protection from the threat of disease, hunger, unemployment, crime, social conflict, political repression, and environmental hazards" (UNDP, 1996). 


\subsubsection{Wealth Creation}

The meaning of wealth has different connotations for different perspectives and people. In general, it means abundance of something which someone or entity possesses with embedded value. In business terms, wealth means products or services generated by a given economic activity, and usually refers to the accumulation of resources by a certain society (Yelwa and Emmanuel, 2013). The concept of 'wealth' varies among societies. Therefore, the word wealth means different things to different people. In its most narrow sense, wealth refers to abundance of anything. But generally, wealth refers to abundance possession of object(s) of value (e.g. gold, clay, water, property, certain skills etc.) and the state of having accumulated these objects. The $\operatorname{IMF}(2003)$ assert that wealth creation can be narrowly defined in terms of income generation or more broadly as the creation of assets, both in terms of physical and human capital. Chukwuwunonyelum (2004) state that wealth creation in simple terms, refers to economic growth and better standard of living for the individual, family or states.

The measurement of wealth creation has been in scholarly discussion for a long time and it has been differently viewed. Otu and Adejumo (2013), Ibadin and Oladipupo (2015) opined that wealth creation is measured as economic growth that is normally measured by Gross Domestic Product (GDP). These scholars conclude that the GDP measures national production for a given period of time in a way that shows capital stock operations, technological advancements, quality of education and healthcare and security services. For a nation, wealth creation is measured by its economic growth which is any kind of increase in production and service activities that sustain the national income for some period of time which is more than one year. This shows that increased employment, capital stock improvement and technical advancement are taking place. An increase in labour force shows that there is an economic activity that 
generates employment for the citizens; the investment climate is fair to all and resources are being equally allocated where there is also increase in production output of a nation and per family or head which is translated as improvement citizens' welfare. Through capital stock, there is increase in investment opportunities since there is availability of finance from primary and secondary capital markets (Lee and Gordon, 2005). Thus, wealth creation requires the development and improvement of basic physical and social infrastructures that improves standard of living in the society. These include construction of schools for education, hospitals for quality healthcare, roads construction, bridges settings, railways, seaports and modern airports. These become facilities for wealth creation among the citizens of a nation (Afuberoh and Okoye, 2014; Adereti, Adesina and Sanni, 2011).

The government's role should be the stabilization of the national economy, improvement of services provision to citizens and redistribution of income among the population in terms of public facilities (Ayuba, 2014). Appah (2010) considered economic growth as a measurement of wealth creation for the nation that comes from the economic activities which are supported by the government's contribution to the business conduct and facilitation in terms of public goods creation. Lymer (2010) and Chigbu and Njoku (2015) are of the opinion that government should have a sound and fair fiscal policy which allows for economic stability, employment provision, externalities balance and sustained economy so that its nation should continually develop and secure its future for the citizenry.

\subsubsection{Economic Growth}

According to Todaro development refers to the multidimensional changes involving progress or improvements in structures, institutions, the general aspects of life of a given people. This entails the acceleration of economic growth, decline of poverty, and the 
reduction of inequality. Growth theorists argued that development is an outcome of economic growth while other scholars like Rostow \& Harrod-Domar (Todaro, 1982, Rostow, 1952, \& Harrod-Domar, 1957 cited in Ewetan \& Urhie, 2014) posited that economic development and growth result from structural changes, savings and investments in an economy. Socio-economic development is measured with indicators, such as GDP, life expectancy, literacy and levels of employment (Nwanegbo \& Odigbo, 2013, Ewetan \& Urhie, 2014). Ugoh \& Ukpere, (2010), views national development as a qualitative and quantitative improvement in the living conditions of people of a state in line with national objectives, as indicated in its national development plans.

According to him, other key objectives of the development plans include: Reduction in the level of unemployment; equitable distribution of income; reduction in the incidence of poverty; improvement in the quality of life of the people; more employment opportunities; greater access to and ownership of houses; and access to basic necessities of life such as qualitative health services, potable water, education and electricity. It is when these objectives are achieved that one can talk of national development. Development is a process of bringing about fundamental and sustainable changes within society. He notes that development transcends as well as encompasses growth and embraces aspects of quality of life such as social justice, equal opportunity for all citizens, equitable distribution of income and democratization of the development process.

Nwanegbo and Odigbo, (2013) describes sustainable development as a construct, which envisions development as meeting the needs of a present generation without compromising the needs of a future generation. It implies that while development meets the needs of the present, it does not compromise the ability of a future generation in order to meet their own needs. Scholars have identified strong links between security and sustainable development since the 
cold war ended. Development cannot be achieved in any nation where there are conflicts, crisis and war. There is a consensus in the literature that security and development are two different and inseparable concepts that affect each other, and this has naturally triggered debates on security-development nexus. Viewed against the backdrop of the Brundtland report, its application to the peculiar condition of the Nigeria territory becomes critical.

\subsubsection{National Security, Wealth Creation and Economic Growth}

The insurgency of Boko Haram in Northern Nigeria owing to religious misconceptions, government neglect, delayed and unfruitful response of security agencies makes it a sustained reality (Mbam, 2011). This makes wealth creation and consequently economic growth a herculean task. Agricultural products such as onions, yams, and beans are trapped in the North owing to terrorism resulting in high cost of food items. This situation renders traders who specialize in marketing of these commodities jobless. For example, on the 5the of July, 2019, 5 traders from Bodija market, Ibadan, Oyo State were murdered by Boko Haram members in the North. In total, Bodija market lost 14 of its members and an estimated 33 million Naira to two attacks in 2019 (Vanguard, 2019). Boko haram insurgency has claimed about 4000 lives, with about 300,000 people displaced while impacting negatively on the livelihoods of an estimated 6 million people (Blanchard, 2014). The aforementioned are not restricted to Nigeria alone. Other countries in Africa as Kenya, Sudan, Egypt and Mali suffer from insecurity. Zimbabwe and Libya experience advanced corruption. Niger republic is plagued with severe poverty in which businesses find it difficult to thrive.

Nigerian entrepreneurs are confronted with the problem of undercapitalization (Anyadike et al., 2012). Some traders sit behind wares not up to 5000naira (USD 22) from morning till night; a situation that depicts poverty. Inadequate access to credit as a result 
of high bureaucratic process of obtaining loans, and 'throat-cutting' interest rates charged by banks make businesses unprofitable.

The Nigerian business environment is characterized by bad roads, epileptic electricity supply, and inadequate access to potable water (Onukwuli et al., 2014). The high cost of transportation resulting from deplorable state of roads in the country and cost of purchase and maintaining generators (on account of epileptic power supply) account for high production costs obtainable in Nigeria. A recent study by the Nigerian Customs Service awarded Nigeria the ridiculous honour as the continent's biggest importer of generators. Private entities spend $\$ 8$ billion to import generators annually. Estimated 60million Nigerian residents spent $\$ 13.35$ billion on fuelling generators in 2012 (GGA, 2013). Inadequate access to basic infrastructure has resulted in high production costs and outright loss of goods in extreme cases. International business organisations with sophisticated technologies, low labour cost and good business environment access Nigerian markets resulting in dumping. This situation renders Nigerian products too costly and inferior in the sight of consumers.

Government policies are inconsistent and contradictory (Agwu and Emeti, 2014). For instance, while there is local rice in Abakaliki (Ebonyi State), Erinmo (Osun State) and Igbimo rice (Ekiti State) among others, government subsidizes foreign rice. The agricultural enterprise being risky and Welfare impacts of social grants in Thulamela local municipality of Limpopo Province South Africa rain-fed business, instead of being subsidized by government is taxed heavily. Inconsistency in government policies has led to business failures. The basis of formulating most of the policies is wrong, coupled with poor implementation has led to policy summersault in some cases.

There is low funding to protect SMEs and when provided, they are diverted to private pockets. Developmental projects are made 
unnecessarily complex to justify the corrupt huge expenses on them. Government at all levels; spend the bulk of Nigerian budget on large and difficult-to-manage projects to encourage fraud through project execution. A high proportion of Nigerian budget is spent on defence and infrastructure rather than provision of necessary public services such as health, roads, housing, schools, electricity and water. Registering of new businesses is faced with bureaucratic complexities and fraud. In fact, Nigeria ranks $129^{\text {th }}$ out of 189 countries in the starting a business index (World Bank, 2014). There is double counting in government taxation; however some corrupt Nigerians evade tax. Nigeria ranks7th in money laundering index with \$12.9 billion being laundered by Nigerian leaders between 2001 and 2010 (Kar and Freitas, 2010). However, proceeds from drug trafficking, human smuggling, and other criminal activities which are often settled in cash were not included in the estimate. If the $\$ 12.9$ billion is spent on provision of public services and monitored, SMEs will flourish consequently leading to economic development.

Weak security system is one of the major contributory factors to the level of insecurity in Nigeria. According to Olonisakin (2008), the police-population ratio in Nigeria is 1 per 450 people which falls below the standard set by the United Nations. The implication of this is that Nigeria is grossly under policed and this partly explains the inability of the Nigerian Police Force to effectively combat crimes and criminality in the country.

Achumba (2013) observe that, the porous frontiers of the country, where individual movements are largely untracked have contributed to the level of insecurity in Nigeria. As a result of the porous borders there is an unchecked inflow of Small Arms and Light Weapons into the country which has aided militancy and criminality. Available data show that Nigeria host over $70 \%$ of about 8 million illegal weapons in West Africa (Edeko, 2011). Poor border made it easy for terrorists, human traffickers and drug barons to infiltrate the 
country and perpetrate heinous crimes and acts of terrorism (Edeko, 2011). There is endemic violence in Nigeria because of availability of, and access to weapons of various type (Onuoha, 2006). These weapons are not normally withdrawn from them and as such, they possess ready tools for kidnapping (Adegeko, 2009).

However, high incidence of poverty, absence of infrastructure and alienation of the local oil communities has engendered kidnapping. As a result of kidnapping, many would be investors declined doing business with the country and in fact many investors have moved out of the region with adverse effect on the economic development of the country. The thought about kidnapping is very frightening; the experience of the crime is traumatic to the victims and their relatives. Its effect on the psyche of the people and it poses serious challenge to various levels of government (Ikpang, 2008, Adegoke, 2007). The rate of kidnapping has taken a new and alarming dimension in Nigeria (Adegoke, 2008). Cases of kidnapping in the Nigeria have resulted in serious injuries, both for civilians, and soldiers. Medical records in the government hospitals show the level and extent of harm inflicted on the kidnapped. The total amount of ransoms paid in Nigeria between 2006 and 2008 exceeded \$100 million. One of the causes of kidnapping in Nigeria is widespread poverty and unemployment. Kidnapping scares away foreign investors. Some foreign multinational companies in the oil, construction and production sectors have closed shops and offices in Nigeria or abroad.

Kidnapping creates fear and insecurity. People live in fear of crime. It reduces the freedom of movement of the people in the affected areas. The social lives of the people has dramatically changed because many who consider themselves as potential victims now shun social outings or patronage of relaxation centres. It reduces the income from the oil as a source of revenue for Federal Government of Nigeria. As early as 2006, it was estimated that with 
the price of oil at $\$ 58$ per barrel, Nigeria will lose about $\$ 6$ million a day due to the closure of the Shell Exploration Production Company (SEPCO) facility (Emmanuel 2006).

\section{Empirical Review}

Akpo and Hassan (2015) found that national security has a significant impact on economic growth in Nigeria. Rapid economic growth and social well-being constitute the development imperative of developing countries of the world and indeed, remain the normative goal of the international community. This involves the attainment of sufficient levels of economic growth to allow for a progressive improvement in the material standard of living of the populace.

Otto and Ukpere (2012) carried out a research on the impact of national security on growth. the work was able to juxtapose the national security expenditure with economic growth to see, if there is any relationship between the spending pattern and growth. This is because growth is critical to development. A stagnating economy is not likely to offer welfare improvements which development proxies. The work observes that there is a positive relationship between security and development in accordance with literature.

In another study by Odesuwa (2011), assert that insecurity in Nigeria has reduced the rate of foreign direct investment in the country. The period of 1990 to 1999 has average FDI inflows of $42 \%$ in Nigeria; however, the period of 2000 to 2009 gave an average rate of FDI inflows of $28 \%$. The reduction in FDI inflows adversely affects exports and growth. Ngagi (2011) in empirical investigation used Granger tests to test whether growth promotes national security or whether national security is determined by the level of output. The finding based on this estimation was inconclusive in the sense that causality runs from economic growth to security. They do not show that national security has a significant impact on growth. In another scenario, Claudia (2010), for instance, also used Granger-Causality 
test and found that there is a bi-directional relationship between both cost of security and GDP. However, with advances in time series econometric techniques, more recent studies have tended to focus on vector error-correction model (ECM) and the co-integration approach, while others are based on the ordinary least squares (OLS) technique.

\section{Method of Analysis}

This study examined national security as a drive of wealth creation and economic growth in Nigeria. The study employs data mainly from the secondary source which are obtained from the CBN database. The time series data cover the period of 1990-2018. In an attempt to estimate the relationship between national security as a drive of wealth creation and economic growth in Nigeria, the following were used; GNI per capita growth (GNIpc) as the dependent variable; while the wealth creation is measure by the employment rate, meaning that the higher the unemployment rate the lower the wealth created in the economy. Thus, unemployment, total (\% of total labour force) (UNR) is used to capture wealth creation. The national security is captured by the Political Stability and Absence of Violence/Terrorism (PST), and Military Expenditure (MEX), and Government Effectiveness (GEF) is brought into the model as a control variable.

Noting that insecurity may affect growth with time lag, an Autoregressive Distributed Lag (ARDL) Model is built for the analysis. It is expected that security exacts positive time lag effects on growth, whilst insecurity negates sustainable growth. The model is anchored on earlier studies like (Maduka, 2009; Odesuwa, 2011; Otto, 2012) with slight modification.

The models are specified in functional form below as:

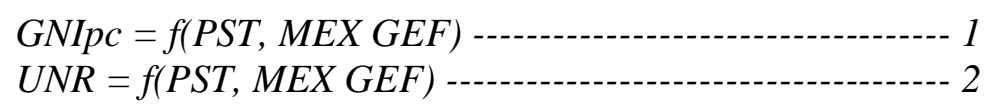


Where GNIpc represents GNI per capita growth (annual \%), PST is the political stability and absence of violence/terrorism rating of the country, MEX is the military expenditure (\% of GDP), UNR is the total unemployment rate (\% of total labour force) (UMP), and GEF is the government effectiveness measure.

Note that the national security measures in this study are in accordance with Ibrahim Index of national security in African including Nigeria. This measure consists of 100 indicators built up into 4 categories: Safety \& Rule of Law, Participation \& Human Rights, Sustainable Economic Opportunity and Human Development. It includes four data types from 36 different sources: Qualitative Assessment, Opinion Surveys, Official Data and Public Attitude Survey. The political stability and absence of violence/terrorism measures perceptions of the likelihood of political instability and/or politically-motivated violence, including terrorism. It ranges from approximately -2.5 (weak) to 2.5 (strong) national security and governance performance. On the other hand, the government effectiveness variable measures perceptions of the quality of public services, the quality of the civil service and the degree of its independence from political pressures, the quality of policy formulation and implementation, and the credibility of the government's commitment to such policies.

The econometric linear expression of the above model in equations $1 \& 2$ is presented as:

$$
\begin{aligned}
& \text { GNIpc }_{t}=\alpha_{0}+\alpha_{1} P S T_{t}+\alpha_{2} M E X_{t}+\alpha_{3} G E F_{t}+U_{t}-\cdots-\cdots-1 \\
& U_{N R}=\alpha_{0}+\alpha_{1} P S T_{t}+\alpha_{2} M E X_{t}+\alpha_{3} G E F_{t}+U_{t}
\end{aligned}
$$

Where, $\alpha_{0}$ is the intercept, $U_{t}$ is the stochastic error term, $\alpha_{1}, \ldots, \alpha_{3}$ are the parameters set for estimation. Expressing equations $3 \& 4$ as an Auto-Regressive Distributed Lag (ARDL) model, equations $5 \& 6$ are formulated.

$$
\begin{aligned}
& \text { GNIpc }_{t}=\alpha_{0}+\alpha_{1} \text { GNIpc }_{t-1}+\alpha_{2} P S T_{t-1}+\alpha_{3} M E X_{t-1}+\alpha_{3} G E F_{t-1}+U_{t--} \\
& U_{N R R_{t}}=\alpha_{0}+\alpha_{1} U_{N R_{t-1}}+\alpha_{2} P S T_{t-1}+\alpha_{3} M E X_{t-1}+\alpha_{3} G E F_{t-1}+U_{t}----6
\end{aligned}
$$


Where $t-1$ is the first lag order of the variables.

\section{Results}

The analysis starts with the unit root result conducted to ascertain the unit root structure of the variables. It shows that all the variables, with the exception of the GNIpc and PST, are integrated of order one, I(1).

\subsection{Unit Root Test Result}

\begin{tabular}{|c|c|c|c|c|}
\hline Variables & ADF Stat & $\begin{array}{c}\text { 5\% Critical } \\
\text { Value }\end{array}$ & $\begin{array}{c}\text { Order of } \\
\text { Integration }\end{array}$ & Remark \\
\hline GNIpc & -5.137714 & -2.986225 & $\mathrm{I}(0)$ & Stationary \\
\hline UNR & -7.273091 & -2.991878 & $\mathrm{I}(1)$ & Stationary \\
\hline PST & -5.730090 & -3.020686 & $\mathrm{I}(0)$ & Stationary \\
\hline MEX & -4.737655 & -2.991878 & $\mathrm{I}(1)$ & Stationary \\
\hline GEF & -8.558765 & -2.976263 & $\mathrm{I}(1)$ & Stationary \\
\hline
\end{tabular}

Source: Author's compilation using EViews9 output

The dependent variable for the first model, GNIpc, is of zero integration order with the measure of national security (political stability and absence of violence/terrorism, PST). Also, in the second model, the dependent variable, unemployment rate is of the same integration order with military expenditure, MEX, and government effective, GEF. Thus, ARDL estimation model is suitable with the above integration pattern. 
Azu, Uduh \& Mobosi: National Security and Wealth Creation: The Nigerian Sustainable Growth Nightmare

4.2 Summary of the estimated ARDL(d) Results

\begin{tabular}{|l|l|l|l|l|}
\hline \multirow{2}{*}{ Variables } & \multicolumn{2}{|c|}{ ANIpc } & \multicolumn{2}{c|}{ UNR } \\
& \multicolumn{1}{|c|}{ t-stat.(Prob) } & \multicolumn{1}{c|}{ Coefficient } & \multicolumn{1}{c|}{ t-stat.(Prob) } \\
\cline { 2 - 5 } & Coefficient & \multicolumn{1}{c}{ ARDL(4, 4) } \\
\hline D(GNIPC(-1)) & -1.545688 & $-4.830590(0.0048)^{* *}$ & & \\
\hline D(GNIPC(-2)) & -0.211881 & $-0.628942(0.5570)$ & & \\
\hline D(GNIPC(-3)) & -0.375597 & $-1.739649(0.1424)$ & & \\
\hline D(UNR(-1)) & & & -0.517626 & $-1.331532(0.2538)$ \\
\hline D(UNR(-2)) & & & -0.874273 & $-1.382674(0.2389)$ \\
\hline D(UNR(-3)) & & & 0.603298 & $1.205651(0.2944)$ \\
\hline D(UNR(-4)) & & & -0.335379 & $-1.171492(0.3064)$ \\
\hline D(PST) & -11.68907 & $-2.801963(0.0379)^{*}$ & -10.57736 & $-3.444953(0.0137)^{* *}$ \\
\hline D(PST(-1)) & -8.234188 & $-1.574683(0.1761)$ & -8.561054 & $-1.985984(0.0942)$ \\
\hline D(PST(-2)) & -15.05704 & $-2.811166(0.0307)^{*}$ & -15.05704 & $-2.811166(0.0307)^{*}$ \\
\hline D(PST(-3)) & -13.29857 & $-2.299988(0.0591)^{*}$ & -13.29857 & $-2.299988(0.0511)^{*}$ \\
\hline D(PST(-4)) & -12.11385 & $-2.453396(0.0577)^{*}$ & -6.613029 & $-1.493510(0.1859)$ \\
\hline D(MEX) & 12.13603 & $3.080551(0.0275)^{*}$ & 10.70254 & $3.616936(0.0111)^{* *}$ \\
\hline D(MEX(-1)) & -21.39111 & $-3.375011(0.0275)^{*}$ & -19.47904 & $-3.855558(0.0084)^{* *}$ \\
\hline D(MEX(-2)) & 23.69953 & $4.201980(0.0085)^{* *}$ & 22.32020 & $4.338188(0.0049)^{* *}$ \\
\hline D(MEX(-3)) & 23.26355 & $3.535653(0.0166)^{* *}$ & 16.61215 & $2.245324(0.0559)^{*}$ \\
\hline D(MEX(-4)) & 17.37417 & $1.698094(0.1502)$ & 8.414547 & $1.212034(0.2711)$ \\
\hline D(GEF) & -56.34760 & $-2.434328(0.0599)^{*}$ & -55.60695 & $-2.603966(0.0404)^{*}$ \\
\hline D(GEF(-1)) & -51.94105 & $2.571817(0.0499)^{*}$ & -53.58308 & $2.362433(0.0561)^{*}$ \\
\hline D(GEF(-2)) & -5.314173 & $-0.241836(0.8185)$ & -13.23374 & $-0.744507(0.4847)$ \\
\hline D(GEF(-3)) & -40.59373 & $2.334188(0.0558)^{*}$ & -27.43533 & $1.720038(0.1362)$ \\
\hline D(GEF(-4)) & -13.13543 & $-0.935493(0.3925)$ & -24.55738 & $-1.846561(0.1143)$ \\
\hline C & 0.165967 & $0.089039(0.9325)$ & -40.93602 & $-2.346012(0.0574)^{*}$ \\
\hline R-squared & & 0.965499 & & 0.887519 \\
\hline DW-statistic & & 1.821608 & & 2.196169 \\
\hline Key: & & & & \\
\hline
\end{tabular}

Key: $*$ and $* *$ represents $1 \%$ and $5 \%$ level of significance, respectively.

Table 4.2 result shows dynamic negative impact of wealth creation and economic growth on its current states. It indicates that a unit increase in their respective shocks in the current year decreases gross national income per capita (GNIpc) by 1.5 units and wealth creation by 0.5 units in the preceding year, other factors remaining constant. 
That is shocks in GNIpc negatively and significantly impact its performance in the next year, but that of wealth creation, though, negative but insignificantly impact its subsequent performances in the preceding years. The above finding corroborates the work of Stewart (2004), who finds that threats to security can have spillover effects including socioeconomic roots, contests over natural resources, environmental degradation, economic and social inequalities, economic and political migration, natural disasters, among others.

The direct negative impact of national security challenges on both wealth creation and economic growth is alarming in Nigeria. Table 4.2 result indicates that a unit increase in national security (the level of political instability and violence/terrorism, PST, rating of the country) concerns would decrease GNIpc by 11.7 units and wealth creation by 10.6 units in the current year. This impact would reduce in a one year lag to 8.2units for GNIpc, and 8.5unit to wealth creation measure, other factors remaining fixed. The impact of PST would increase in the lag 2 period, with 15.1unit impact on both GNIpc and wealth creation, respectively. The negative impact of national security on wealth creation and economic growth goes beyond two years lag, however, after the $2^{\text {nd }}$ years lag, the impact would slow down gradually. For the GNIpc, it slowed from 15.1units impact in the $2^{\text {nd }}$ year to 13.3 units in the $3^{\text {rd }}$ year and 12.1 units in the $4^{\text {th }}$ year respectively, while that of wealth creation shows a slowdown from 15.1unit in the $2^{\text {nd }}$ year to 13.3 units in the $3^{\text {rd }}$ year and 6.6units in the $4^{\text {th }}$ year respectively.

The above finding is in line with literature, lack of security negatively affect wealth creation by increasing unemployment. It results in the shutdown of businesses and the relocation of companies from unsafe to safe havens. Stewart (2004) stressed that the economic cost of insecurity as enormous, as people who joined the fighting forces or killed or flee as a result of national security challenges, can no longer work productively. Schools, power stations, and roads that 
are destroyed during crises period and this reduce the productive capacity of the economy. Displacement of people during national security crisis reduces the production of exports, thereby reducing foreign exchange earnings, import potentials and consequently further constraining output, leading to a decline in employment and earnings (Achumba \& Ighomereho, 2013). People affected by insecurity are not only uncertain or unaware of what would happen but they are also not able to stop it or protect themselves when it happens. In his own, Onime, (2018), find that insecurity affects economic growth by drying-out investments, increases unemployment and dwindles government revenue, amongst others.

Another national security variable introduced into that analysis is the level of military expenditure (MEX) in the economy. It is believe that the high the national security challenges, the high the level of military expenditure by the government. In effect, the study result shows that military expenditure would significantly and positively impact on wealth creation and economic growth in the current year, but decrease both wealth creation and economic growth in the preceding one year lag. It shows that a unit point increase in MEX would increase wealth creation by 10.7 units and economic growth by 12.1 units, other factors remaining fixed. The result further shows that a unit point increase in military expenditure, in a one year lag, would decrease wealth creation by 19.5 units and economic growth by 21.4 units, respectively.

The result also indicate that, apart from the negative impact of national security challenges to wealth creation and economic growth in Nigeria, another major determinant is the effectiveness of the governance. The poor rating of the country's government effectiveness indicates huge negative impact on both wealth creation and economic growth. Unit point increase government ineffectiveness (low effectiveness rating) would decrease wealth creation by 55.6units and economic growth by 56.3units. In one year lag, the 
negative effect of poor governance on wealth creation reduces to 53.6units, while that of economic growth reduces to 51.9units, other variables remaining constant.

\section{Conclusion}

Any country or state replete with security challenges can hardly attract meaningful investments that create wealth or grow her economy. This paper examined the nexus between national security, wealth creation and economic growth in Nigeria. The severity and intensity of security challenges in Nigeria have derailed the nation from its growth trajectory. Wealth creation and economic growth have been badly challenged due to massive and still growing unemployment in the land. The level and severity of security challenges in the nation have casted doubt on the seriousness of the government of the nation. Government effectiveness of the nation has been very low. Economic analysts have called for concerted and wellarticulated security policies to address the hydra-headed problem. Many have suggested the need for holistic and sustainable measures, understanding the root causes of insecurity so as to target the right solution to addressing the challenge. Such solutions must be such that should be long lasting and all-encompassing to avoid a recurrence.

\section{Benedict Azu, PhD}

Department of Ecnomics, College of Education, Agbor Delta State;

\section{Uduh, Dominic Mario Uduh, PhD}

Department of Ecnomics, College of Education, Agbor Delta State. $\&$ 


\section{Andrew I. Mobosi, PhD}

Department of Economics,

University of Nigeria, Nsukka

\section{References}

Achumba Ighomereho and Akpor-Robaro (2013). 'Security Challenges in Nigeria and the Implications for Business Activities and Sustainable Development', Journal of Economics and Sustainable Development, Vol.4, No.2, 2013 79. ISSN 2222-1700 (Paper) ISSN 2222-2855 (Online).

Adebakin, M.A., \& Raimi, L. (2012). National security challenges and sustainable economic development: Evidence from Nigeria. Journal of Studies in Social Sciences, 1(1), 1-30.

Adegoke, N. (2009). Kidnapping, Security Challenges and SocioEconomic Implications to the Niger Delta Region of Nigeria. Niyi Adegoke, 16(2), 205-216.

Anyadike, N.O (2013). Boko Haram and National Security Challenges in Nigeria; Causes and Solutions. Journal of Economics and Sustainable Development, 4 (5) 12-23.

Babangida, M. A. (2012). The Search for National Security in Nigeria: Challenges and Prospects. A Paper Presented at Obafemi Awolowo Institute of Government and Public Policy, Agip Recital Hall, Muson-Lagos; Thursday, 27th September, 2012.

Chris, I. N. (2012) Security Challenges and Economy of the Nigerian State (2007 - 2011). American International Journal of Contemporary Research 2(6): $244-258$.

Claudia, A. (2010). Parameters of Nigeria's Defence Policy in National Interest, National Security and Defence Policy Revisited, Minna, Tradoc, 311-324

Ekpo, Akpan H (2013) Promoting Inclusive Development in Nigeria: Issues of Policy Reforms and Expectations from economic 
agents, Distinguished public lecture, Department of Economics, University of Lagos.

Ewetan, O. O. (2013). Insecurity and Socio-Economic Development:

Perspectives on the Nigerian Experience. A lecture Delivered

St. Timothy Anglican Church, Sango-Ota, Ogun State, .

Ewetan, Olabanji and Urhie, Ese (2014). 'Insecurity and Socio-

Economic Development in Nigeria'. Journal of Sustainable

Development Studies ISSN 2201-4268 Volume 5, Number 1.

Global Peace Index (GPI, 2012). Global Peace Ranking. Institute for

Economic and Peace, Retrieved From Wikipedia, the free encyclopedia. Journal of Sustainable Development Studies 62

Harrod, R. F., \& Domar, E. (1957). Essays on the Theory of Economic Growth. Oxford University Press, London.

Ikelegbe, A. (2008). Interrogating a Crisis of Corporate Government and the Interface with Conflict in the Niger-Delta. A Paper Presented at the International Conference on the Nigerian State, Oil Industry and the Niger-Delta, held at Glory Land Cultural Centre, Yenagoa, Bayelsa State on March 11 -13 .

Ngagi, S. (2011). People, States, and Fear: the National Security

Problems in Nigeria. Wheatsheaf Books, 67.

Nwanegbo, C.J and Odigbo, J. (2013). Security and National Development in Nigeria. The Threat of BokoHaram. International Journal of Humanities and Social Science, 3 (4), 285-391.

Nwanegbo, C.J. \& Odigbo, J. (2013). Security and National

Development in Nigeria: The threat of Boko Haram.

Retrieved 22.07.2014 from

Odesuwa, O. A. (2011). "Foreign Investment and National Security".

In Proceedings of the 33rd Annual Conference of the Nigerian Society of International Law held at Benin City. 
Orji, K. E. (2012). National Security and Sustainable Development in Nigeria: Challenges from the Niger Delta. African Research Review, 6 (1): 198 - 2011.

Omede, J. (2011). Reformatting Nigerian Secondary and post secondary education to meet unemployment and security challenges in Nigeria in the 21st century. Research Journal in Organizational Psychology and Educational Studies (RJOPES). Available at http://www.emergingresource.org

Onime, B. E., (2018). Insecurity and Economic Growth in Nigeria: A Diagnostic Review. European Scientific Journal February 2018 edition Vol.14, No.4 ISSN: 1857 - 7881 (Print) e - ISSN 1857- 7431

Otto, G and Ukpere, W. I. (2012). National security and development in Nigeria. African Journal of Business Management Vol.6 (23), pp. 6765-6770.

Oladeji, S. I., \& Folorunso, B. A. (2007). The Imperative of National Security and Stability for Development Process in Contemporary Nigeria. European Journal of Social Sciences, 3(2), 66-79.

Olonisakin, F. (2008). "In the Line of Fire", BBC Focus on Africa, (April-June), pp19-23.

Onuoha, G. (2006). Contextualizing the Proliferation of Small Arms and Light Weapons in Nigeria's Niger Delta. Africa Security Review, 15(2).

Pearce, D. \& Barbier, E. (2000) Blueprint for a Sustainable Economy. Earthscan Publications Ltd, London.

Rostow, W. (1952). The Process of Economic Growth. New York. Norton and Co. Inc.

Stewart, Frances (2004). 'Development and Security', WORKING PAPER 3, Centre for Research on Inequality, Human Security and Ethnicity, CRISE Queen Elizabeth House, University of Oxford. 
Ugoh, C. S. \& Ukpere, I. W. (2010) Oil politics and the Niger Delta Developmental Conundrum. African Journal of Business Management 4(6): 1166-1174.

UNDP (1994). Human Development Report. New York: Oxford University press

United Nations Development Programme (UNDP), (1996). United Nations Development Programme, Human Development Report, Lagos.

Vanguard (Wednesday, August 6th, 2014). 12000 lives lost to Boko Haram-Joanthan.

Williams, P. (2008), Violent Non-State Actors and National and International Security, International Relations and Security Network Series, Zurich: Swiss Institute of Technology. Retrieved March 16, 2009. 